\title{
Phosphorus Utilization Efficiency by Sunflower (Helianthus annuus L.) from Sparingly Soluble P Source under P Deficient Environment
}

\author{
Hafiz Hammad ${ }^{1}$, Mukkram Ali Tahir ${ }^{1}$, Noor-Us-Sabah ${ }^{1 *}$, Ghulam Sarwar ${ }^{1}$, Muhammad Aftab ${ }^{2}$, Muham- \\ mad Zeeshan Manzoor ${ }^{1}$, Aneela Riaz ${ }^{3}$, Abid Niaz ${ }^{4}$ and Muhammad Arif ${ }^{4}$
}

${ }^{1}$ Department of Soil and Environmental Sciences, College of Agriculture, University of Sargodha, Sargodha, Pakistan; ${ }^{2}$ Institute of Soil Chemistry and Environmental Sciences, Ayub Agricultural Research Institute, Faisalabad, Pakistan; ${ }^{3}$ Soil Bacteriology Section, Ayub Agriculture Research Institute, Faisalabad, Pakistan; ${ }^{4}$ Institute of Soil Chemistry and Environmental Sciences AARI Faisalabad, Pakistan.

Abstract | In order to scrutinize the phosphorus acquisition efficiency of sunflower from sparingly soluble $\mathrm{P}$ source i.e. Rock Phosphate (RP), a pot research was conducted by growing sunflower (Helianthus annuus L.) in P deficient environment at research area, College of Agriculture, University of Sargodha in year 2018. The experiment was laid out in a complete randomized design (CRD) with eight treatments which were replicated four times. The treatments plan includes $\mathrm{T}_{1}=\mathrm{NK}+\mathrm{P}_{0}$ (Control); $\mathrm{T}_{2}=\mathrm{NPK}$ (Recommended rate);

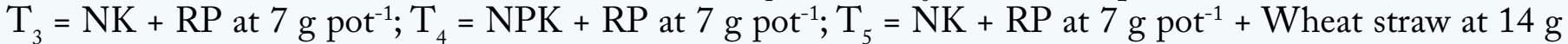
$\operatorname{pot}^{-1} ; \mathrm{T}_{6}=\mathrm{NK}+\mathrm{RP}$ at $7 \mathrm{~g}$ pot $^{-1}+$ Wheat straw at $28 \mathrm{~g} \mathrm{pot}^{-1} ; \mathrm{T}_{7}=\mathrm{NK}+\mathrm{RP}$ at $7 \mathrm{~g} \mathrm{pot}^{-1}+$ Rice straw at $14 \mathrm{~g}$ pot $^{-1} ; \mathrm{T}_{8}=\mathrm{NK}+\mathrm{RP}$ at $7 \mathrm{~g}$ pot $^{-1}+$ Rice straw at $28 \mathrm{~g} \mathrm{pot}^{-1}$. Observations regarding $\mathrm{P}$ accumulation, plant $\mathrm{P}$ concentration, $\mathrm{P}$ uptake efficiency and $\mathrm{PE}$ ratio were recorded using standard procedures and obtained data was analyzed statistically with a statistical software Statistix 8.1 analysis of variance technique and significant of treatments was tested using LSD test at probability level of 5\%. The maximum $\mathrm{P}$ accumulation (178.37 $\mathrm{mg} \mathrm{P}$ pot $\left.^{-1}\right), \mathrm{P}$ uptake efficiency (1.90) and $\mathrm{PE}$ (phosphorus efficiency) ratio $\left(747.15 \mathrm{~g} \mathrm{DM}\left(\mathrm{g}\right.\right.$ plant $\left.{ }^{-1}\right)$ of $^{-}$ sunflower was observed with application of $\mathrm{NK}+$ Rock phosphate at $7 \mathrm{~g} /$ pot + Wheat straw at $28 \mathrm{~g} \mathrm{pot}^{-1}$ $\left(\mathrm{T}_{6}\right)$ in cultivar Hysun-33. While, the lowest value of $\mathrm{P}$ accumulation (89.13 $\left.\mathrm{mg} \mathrm{P}^{\mathrm{P}} \mathrm{pot}^{-1}\right), \mathrm{P}$ uptake efficiency (1.18) and PE ratio (605.0 g DM (g plant $\left.{ }^{-1}\right)$ was noted under $\mathrm{NK}+\mathrm{P}_{0}\left(\mathrm{~T}_{1}\right)$ treatment in Agwara-3. Among the tested sunflower cultivars, Hysun-33 showed superiority over Agwara-4.

Received | December 06, 2020; Accepted | January 22, 2021; Published | April 07, 2021

*Correspondence | Noor-us-Sabah, Department of Soil and Environmental Sciences, College of Agriculture, University of Sargodha, Sargodha, Pakistan; Email: soilscientist.uca@gmail.com

Citation | Hammad, H., M.A. Tahir, N.U. Sabah, G. Sarwar, M. Aftab, M.Z. Manzoor, A. Riaz, A. Niaz and M. Arif. 2021. Phosphorus utilization efficiency by sunflower (Helianthus annuus L.) from sparingly soluble $\mathrm{P}$ source under $\mathrm{P}$ deficient environment. Pakistan Journal of Agricultural Research, 34(2): 294-299.

DOI | http://dx.doi.org/10.17582/journal.pjar/2021/34.2.294.299

Keywords | Organic amendment, Phosphorus, Sunflower, Rock phosphate, Deficient

\section{Introduction}

Sunflower ranked $4^{\text {th }}$ with respect to significance and largest producible vegetable oil crop in the world. Russia, Ukraine and Argentina producing $82 \%$ of total sunflower oil (Prolea, 2012). About 50\% of the whole world's sunflower seed production is carried out in European countries. Sunflower crop has its own unique and delicate types of structure. This crop is one of most demanding crop of $20^{\text {th }}$ century due to its unique characteristics, oil content, nutritious significance and water use efficiency when contrasted with crops of same group (Diepenbrock and Pasda, 1995). 
It was introduced in Pakistan, as an oil seed crop about 50 year ago. In Pakistan, the average yield of sunflower seed is about 1.3 tons $\mathrm{ha}^{-1}$. Its oil contents in seed varied between $35 \%-55 \%$. This crop has wide adaptability and can grow in all types soil and climate (Barani as well as irrigated). According to FAO (2014), the sunflower total harvested area in Pakistan was 152,675 ha, where total seed produced was 3240 tonnes. According to economic survey of Pakistan oil consumption was 2.905 million tons production during fiscal year 2015-16. Out of this only $27 \%$ of this need was fulfilled by our local producers while rest was exported costing 44 billion rupees (Economic Survey of Pakistan, 2018-2019).

Achene (seed of Sunflower) is predominantly grown for its oil contents. Achene oil content was greater than the seed oil content of soybean and rapeseed (Prolea, 2009). It is usually used for cooking purpose such as deep frying, pre-cooked meals and salad dresser. Sunflower has great potential for bio fuel and environmental friendly chemicals. The seed of sunflower is also use to produce seed cakes which can be use as animal feed. It is also used to produce bird feed, bakery products, body painting, for medical purpose such as treatment of spider bites and snake bites, warts, ousting worms and refining eyesight (Borredon et al., 2011).

For higher yield role of nutrient is of prime importance. Among essential nutrients role of phosphorus $(\mathrm{P})$ is undeniable (Chen et al., 1994). In plant, phosphorus plays vital role in major process of plant life like reproductive growth of plant is governed by and affected by presences and absences of $\mathrm{P}$ (Wojnowska etal., 1995). Hussain et al. (2006) reported that growth of plants and crops is highly influenced by presences and absences of $\mathrm{P}$. Phosphorus plays vital role in major process of plant like photosynthesis, cell division and nucleus formation (Ayub et al., 2002). For utilization of starch and sugar $\mathrm{P}$ is needed. For reproduction and growth energy is stored in phosphate compounds after photosynthesis. Ali et al. (2002) revealed that $\mathrm{P}$ can easily transport within plant form tissues of older age to younger through cell of root, stem or leaves.

Negative balance of $\mathrm{P}$ is observed in soils (Ahmad and Rashid, 2003) and 80\% Pakistani soils are deficient in $\mathrm{P}$ and major reason is high $\mathrm{pH}$ and nature of soil either calcareous and salinity (Memon, 2005) and this is chief reason due to which $\mathrm{P}$ is present in changed solubility as calcium phosphates. So it is need of time to overcome this issue. There are several ways which can be used to combat this situation like use of mineral fertilizer. It is very simple and effective way to fulfil the requirement of soil and crop but there is very serious issue with this method which is that these types of fertilizer are not good for environmental health and are very expensive which cannot be afforded by ever farmer because of its cost (Gahoonia et al., 2000). Another demerit of using these sources is rate of $\mathrm{P}$ applied that highly affect to $\mathrm{P}$ availability to soil and crop. Some other factors which affect $\mathrm{P}$ availability are type, chemical composition, texture of soil, moisture of soil, type of fertilizer applied, time of application and method of application (Mohanty et al., 2006).

Aziz et al. (2006) described that insufficiency of phosphorus is a genuine worry for productivity and efficiency around the world. When $\mathrm{P}$ is applied in calcareous soils, $\mathrm{P}$ reacts with calcium and produced insoluble compounds after expansion to calcareous soils. To study phosphorus use proficiency of sunflower genotypes, a trail was conducted by Soomro et al. (2018). Eight cultivars were used and $N$ and $P$ were applied at 100-50 and 100-90 kg ha ${ }^{-1}$. Effect of genotypes and treatment and combination of both i.e. impact of expanded $\mathrm{P}$ level and cultivars were affected contents of $\mathrm{P}$ in seed and leaf. A direct relation between $\mathrm{P}$ fertilizer rate and genotypes of sunflower was observed but among genotypes, significant response towards $\mathrm{P}$ use efficiency ratio was observed.

Considering above mentioned facts this research was planned to investigate the $\mathrm{P}$ sources and plant traits enhancing $\mathrm{P}$ acquisition and use efficiency in sunflower grown under $\mathrm{P}$ stress environment and to find the effect of rock phosphate and organic sources of $\mathrm{P}$ on $\mathrm{P}$ acquisition efficiency of sunflower.

\section{Materials and Methods}

A pot research was conducted to scrutinize the phosphorus acquisition efficiency of sunflower grown in $\mathrm{P}$ deficient environment at research area, College of Agriculture, University of Sargodha during 2018. Soil analysis was performed before the sowing of the crop. At the depth of 0-10 and 10-20 cm sampling of soil was done by using soil auger. The soil was sandy loam and had a good drainage capacity. Various physiochemical possessions of soil are shown in Table 1 . The experiment was laid out in a Complete Randomized 
Design (CRD) with eight treatments which were replicated thrice. Treatments include $\mathrm{T}_{1}=\mathrm{NK}+\mathrm{P}_{0}$ (Control without any external $\mathrm{P}$ source); $\mathrm{T}_{2}=\mathrm{NPK}$ (Recommended dose); $\mathrm{T}_{3}=\mathrm{NK}+\mathrm{RP}$ at $7 \mathrm{~g} \mathrm{pot}^{-1} ; \mathrm{T}_{4}$ $=\mathrm{NPK}+\mathrm{RP}$ at $7 \mathrm{~g} \mathrm{pot}^{-1} ; \mathrm{T}_{5}=\mathrm{NK}+\mathrm{RP}$ at $7 \mathrm{~g} \operatorname{pot}^{-1}+$ Wheat straw at $14 \mathrm{~g} \mathrm{pot}^{-1} ; \mathrm{T}_{6}=\mathrm{NK}+\mathrm{RP}$ at $7 \mathrm{~g} \mathrm{pot}^{-1}$ + Wheat straw at $28 \mathrm{~g} \mathrm{pot}^{-1} ; \mathrm{T}_{7}=\mathrm{NK}$ RP at $7 \mathrm{~g} \mathrm{pot}^{-1}$ + Rice straw at $14 \mathrm{~g} \mathrm{pot}^{-1} ; \mathrm{T}_{8}=\mathrm{NK}+\mathrm{RP}$ at $7 \mathrm{~g} \mathrm{pot}^{-1}+$ Rice straw at $28 \mathrm{~g} \mathrm{pot}^{-1}$. The soil was composed from $30 \mathrm{~cm}$ of upper soil layer of a cultivated field and filled in the pots@20 kg in each pot. The desired levels of N, $\mathrm{P}, \mathrm{K}$, rock phosphate, wheat and rice straw were added and thoroughly mixed in soil before the filling of pots. Three healthy seeds of Helianthus annuus L. cultivar Hysun-33 and Agwara-3 were sown separately in each earthen pot. The two healthy seedlings were maintained of each cultivar in each pot after 15 days of sowing. The evacuated plants were assimilated in the similar pot. Plants were watered when needed. Pots were kept free of weeds by hoeing after regular duration. The leaf samples were collected after 40 days of sowing for the determination of $\mathrm{P}$ concentration and accumulation. Plant $\mathrm{P}$ content was determined by using spectrophotometer. Phosphorus uptake efficiency was estimated to the procedure designated by Moll et al. (1982) by dividing the amount of total collected $\mathrm{P}$ per pot $\left(\mathrm{g}\right.$ pot $\left.^{-1}\right)$ by exterior phosphorus amount $\left(\mathrm{g} \mathrm{pot}^{-1}\right)$. Phosphorus efficiency ratios (PER) was determined from the procedure reported by Gerloff and Gabelmann (1983) from which PER was estimated as total plant dry mass $\left(\mathrm{g} \mathrm{pot}^{-1}\right)$ divided by total accumulated $\mathrm{P}\left(\mathrm{g}\right.$ pot $\left.^{-1}\right)$.

The noted data was examined with a statistical software Statistix 8.1 analysis of variance technique and significant of treatments was tested using LSD test at probability level of 5\% (Steel et al., 1997).

Table 1: Soil physio-chemical characteristics before crop sowing.

\section{Characteristics}

$\begin{array}{llll} & \mathbf{0 - 1 0} \mathbf{~ c m} & \mathbf{1 0 - 2 0} \mathbf{~ c m} & \text { Mean } \\ \mathrm{EC}\left(\mathrm{dS} \mathrm{m}^{-1}\right) & 0.40 & 0.53 & 0.46 \\ \text { Soil pH } & 7.8 & 8 & 7.9 \\ \text { Organic matter }(\%) & 0.98 & 1.04 & 1.01 \\ \mathrm{~N}(\%) & 0.38 & 0.25 & 0.31 \\ \text { Available P (ppm) } & 6.4 & 9.1 & 7.75 \\ \text { Extractable K (ppm) } & 134 & 127 & 130.5\end{array}$

Texture class Sandy clay loam Sandy clay loam

\section{Results and Discussion}

\section{$P$ accumulation ( $m g$ P pot ${ }^{-1}$ )}

The accumulation of $\mathrm{P}$ in plants is key attribute that meaningfully enhanced the development and yield of crops. More $\mathrm{P}$ accumulation resulted in higher growth and yield characteristics of sunflower. Data about the analysis of variance for $\mathrm{P}$ accumulation $\left(\mathrm{mg} \mathrm{P}\right.$ pot $\left.^{-1}\right)$ of sunflower clearly showed that impact of different phosphorus combinations on sunflower cultivars was significant. Data showed in Figure 1 exposed that maximum $\mathrm{P}$ accumulation $(178.37 \mathrm{mg}$ $\mathrm{P}$ pot $\left.^{-1}\right)$ was perceived in pots where $\mathrm{NK}+\mathrm{RP}$ at 7 g pot ${ }^{-1}+$ Wheat straw at $28 \mathrm{~g} /$ pot $\left(\mathrm{T}_{6}\right)$ was applied in sunflower cultivar Hysun-33 which was followed by $\mathrm{NK}+\mathrm{RP}$ at $7 \mathrm{~g} / \mathrm{pot}+$ Rice straw at $28 \mathrm{~g} \mathrm{pot}^{-1}$ $\left(\mathrm{T}_{8}\right)$ that produced $173.57 \mathrm{mg} \mathrm{P}$ pot $^{-1} \mathrm{P}$ accumulation fresh in the same cultivar. While, the lowest value of $\mathrm{P}$ accumulation (89.13 $\mathrm{mg} \mathrm{P}^{\mathrm{P}}$ pot $^{-1}$ ) was detected where $\mathrm{NK}+\mathrm{P}_{0}\left(\mathrm{~T}_{1}\right)$ was applied under sunflower cultivar Agwara-3. It is also showed that among the tested sunflower cultivars, higher values of $\mathrm{P}$ accumulation were recorded in Hysun-33 over Agwara-4. Abbadi and Gerendás (2012) also described similar findings to our results who stated that $\mathrm{P}$ accumulation in the sunflower plants increased by applying $\mathrm{P}$ under $\mathrm{P}$ deficit soil. According to Abbadi (2007) a significant enhancement in $\mathrm{P}$ accumulation has been observed in sunflower with $\mathrm{P}$ application.

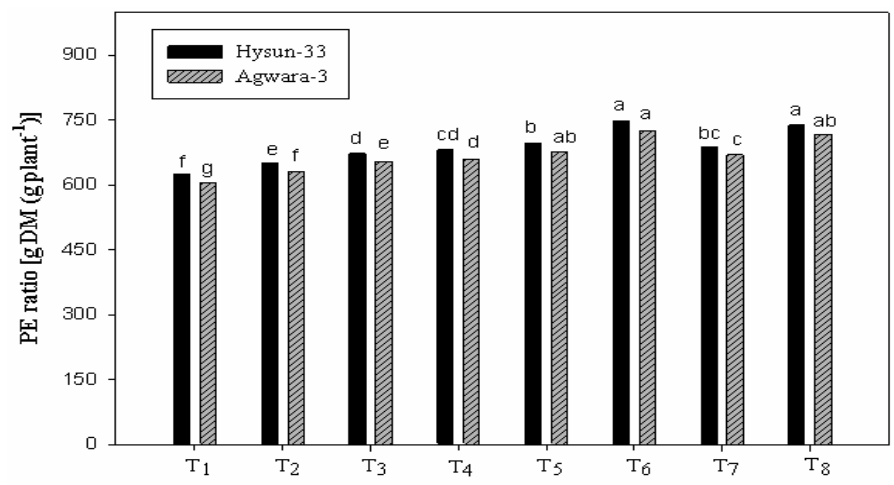

Figure 1: Effect of different $P$ combinations on $P$ accumulation ( $m$. $P$ pot $\left.^{-1}\right)$ of sunflower grown under $P$ deficient environment.

\section{Plant $P$ concentration ( $m g$ P plant ${ }^{-1}$ )}

The yield response of sunflower as swayed by $\mathrm{P}$ contents in new established blade. By enhancing the supply of $\mathrm{P}$, the nutrient status of the plant also improve that significantly increases the yield of sunflower. Influence of various phosphorus combinations on plant $\mathrm{P}$ concentration ( $\mathrm{mg} \mathrm{P}$ plant $^{-1}$ ) of sunflower was found significant. Data (Figure 2) indicated that all combination of phosphorus increased the plant $\mathrm{P}$ 
concentration of sunflower in both tested cultivars as compared to control treatment. Application of NK $+\mathrm{RP}$ at $7 \mathrm{~g} \operatorname{pot}^{-1}+$ Wheat straw at $28 \mathrm{~g} \operatorname{pot}^{-1}\left(\mathrm{~T}_{6}\right)$ produced statistically similar results in both tested cultivars (Hysun-33 and Agwara-3). However, the slightly higher value of $\mathrm{P}$ concentration $(1.78 \mathrm{mg} \mathrm{P}$ plant $^{-1}$ ) was observed in Hysun-33 under $\mathrm{T}_{6}$. Whereas, lowest plant $\mathrm{P}$ concentration (1.04 $\mathrm{mg} \mathrm{P}^{\mathrm{P}}$ plant $^{-1}$ ) was recorded under $\mathrm{NK}+\mathrm{P}_{0}\left(\mathrm{~T}_{1}\right)$ which was followed by the same treatment in Hysun-33. It is clearly observed from the data exhibited in Figure 3 that more plant $\mathrm{P}$ concentration was obtained in cultivar Hysun-33 as compared to Agawara-3 under all treatments. The improvement in plant $\mathrm{P}$ concentration in sunflower may be due to more availability and uptake of plants under the $\mathrm{NK}+$ Rock phosphate at $7 \mathrm{~g} \mathrm{pot}^{-1}+$ Wheat straw at $28 \mathrm{~g} \mathrm{pot}^{-1}\left(\mathrm{~T}_{6}\right)$ treatment. Similar to our outcomes Abbadi (2017) also found that more P has been accumulated in sunflower under $\mathrm{P}$ application that enhances the plant $\mathrm{P}$ concentration in sunflower.

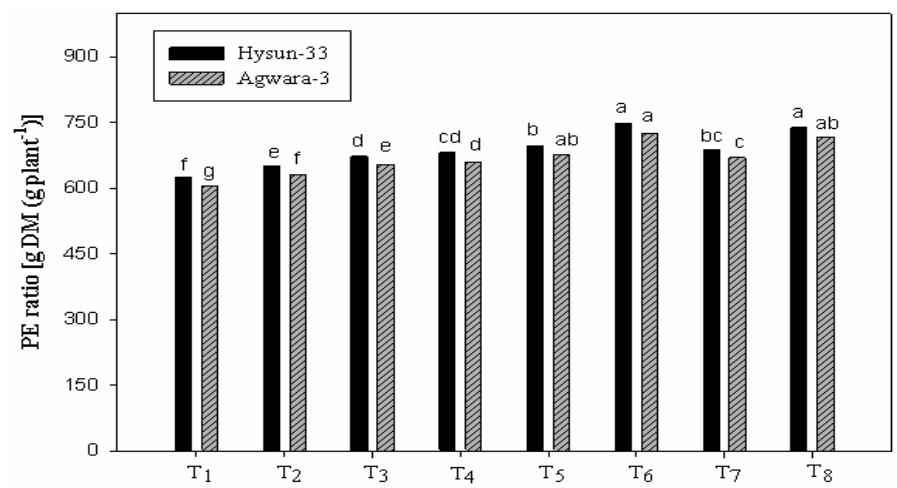

Figure 2: Effect of different $P$ combinations on plant $P$ concentration ( $m g$ P plant ${ }^{-1}$ ) of sunflower grown under $P$ deficient environment.

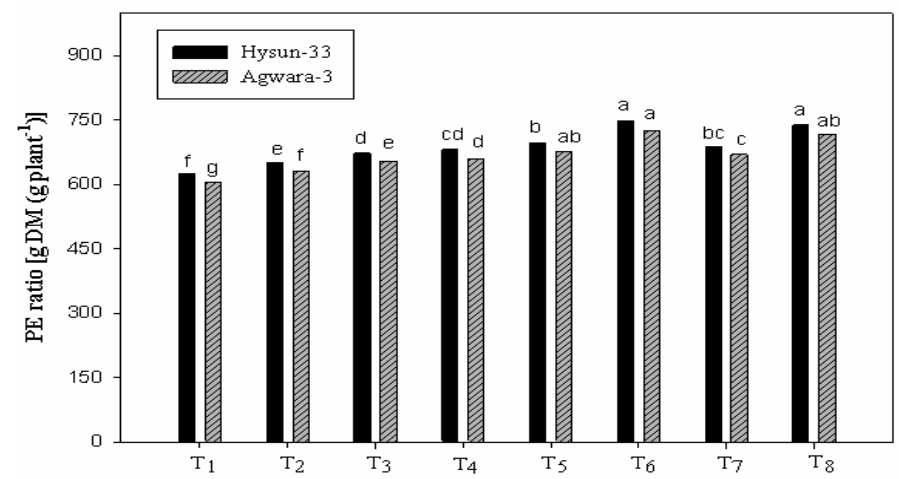

Figure 3: Effect of different $P$ combinations on $P$ uptake efficiency of sunflower grown under $P$ deficient environment.

\section{P uptake efficiency}

As $\mathrm{P}$ is the macro nutrients that plant required in large quantity to perform various functions. If the plants $\mathrm{P}$ uptake efficiency improves then plants perform most of the functions normally that increases the growth and yield of crop. A significant effect of all phosphorus combinations on $\mathrm{P}$ uptake efficiency of sunflower was detected. The highest $\mathrm{P}$ uptake efficiency (1.90) was measured with cultivar Hysun-33 under NK + RP at $7 \mathrm{~g} \mathrm{pot}^{-1}+$ Wheat straw at $28 \mathrm{~g} \mathrm{pot}^{-1}\left(\mathrm{~T}_{6}\right)$ application. The application of NK $+\mathrm{RP}$ at $7 \mathrm{~g} \mathrm{pot}^{-1}+$ Rice straw at $28 \mathrm{~g} /$ pot $\left(\mathrm{T}_{8}\right)$ and $\mathrm{NK}+\mathrm{RP}$ at $7 \mathrm{~g}$ pot $^{-1}+$ Wheat straw at $28 \mathrm{~g} \mathrm{pot}^{-1}\left(\mathrm{~T}_{6}\right)$ produced statistically similar results in Hysun-33 and Agwara-3 respectively. However, the minimum $P$ uptake efficiency (1.18) was recorded under $\mathrm{NK}+\mathrm{P}_{0}\left(\mathrm{~T}_{1}\right)$ in Agwara-4 (Figure 3). The sunflower cultivar Hysun-33 was more efficient in $\mathrm{P}$ uptake as compared to Agwara-3 under all applied combinations of phosphorus. The work of the previous researcher Kaffka et al. (2001) also reported that by application of $\mathrm{P}$ the more availability of $\mathrm{P}$ present in the soil from which $\mathrm{P}$ uptake efficiency of plants has been increased. Our results are further supported by the findings of Abbadi and Gerendás (2011) who revealed that $\mathrm{P}$ uptake efficiency of sunflower enhanced significantly with $\mathrm{P}$ application under $\mathrm{P}$ deficit soil.

\section{$P E$ ratio $\left[g D M\left(g\right.\right.$ plant $\left.\left.^{-1}\right)\right]$}

As an appropriate mean of conveying consumption productivity with reverence to $\mathrm{P}$, the $\mathrm{PE}$ ratio is extensively used that is defined as the biomass production or yield (achene or oil) per unit $P$ accumulated. Effect of various phosphorus combinations on $\mathrm{PE}$ ratio of sunflower was found significant.Data demonstrated in Figure 4 directed that all combination of phosphorus significantly boosted the $\mathrm{PE}$ ratio of sunflower in both tested cultivars as compared to control treatment. The highest $\mathrm{PE}$ ratio (747.15 g DM (g plant ${ }^{-1}$ ) of sunflower was observed with application of NK + Rock phosphate at $7 \mathrm{~g} /$ pot + Wheat straw at $28 \mathrm{~g} \mathrm{pot}^{-1}\left(\mathrm{~T}_{6}\right)$ in cultivar Hysun-33. The treatments containing $\mathrm{NK}+\mathrm{RP}$ at $7 \mathrm{~g}^{\mathrm{pot}}{ }^{-1}+$ Rice straw at $28 \mathrm{~g} \mathrm{pot}^{-1}\left(\mathrm{~T}_{8}\right)$ and $\mathrm{NK}+\mathrm{RP}$ at $7 \mathrm{~g}$ pot $^{-}$ ${ }^{1}+$ Wheat straw at $28 \mathrm{~g} \mathrm{pot}^{-1}\left(\mathrm{~T}_{6}\right)$ produced 738.25 and $725.67 \mathrm{~g}$ DM (g plant ${ }^{-1} \mathrm{PE}$ ratio in Hysun-33 and Agwara-3, respectively. However, the lowest PE ratio $\left(605 \mathrm{~g}\right.$ DM (g plant ${ }^{-1}$ ) was noted under NK + $\mathrm{P}_{0}\left(\mathrm{~T}_{1}\right)$ treatment. It was also alleged from the data displayed that the increase in $\mathrm{PE}$ ratio was more in cultivar Hysun-33 as compared to Agawara-3 (Figure 4). The increase in the $\mathrm{PE}$ ratio with $\mathrm{NK}+\mathrm{RP}$ at 7 g pot ${ }^{-1}+$ Wheat straw at $28 \mathrm{~g} \mathrm{pot}^{-1}\left(\mathrm{~T}_{6}\right)$ may be due to more availability of nutrients to sunflower that reactive in augmenting their consumption proficiency poor $\mathrm{P}$ status soil. These fallouts are reinforced by the 
conclusions of Abbadi and Gerendás (2012) who informed that $\mathrm{PE}$ ratio in sunflower augmented with P supply. Similarly, Abbadi and Gerendás (2011) also reported that $\mathrm{PE}$ ratio of sunflower increased by improving in the $\mathrm{P}$ concentration in the plants.

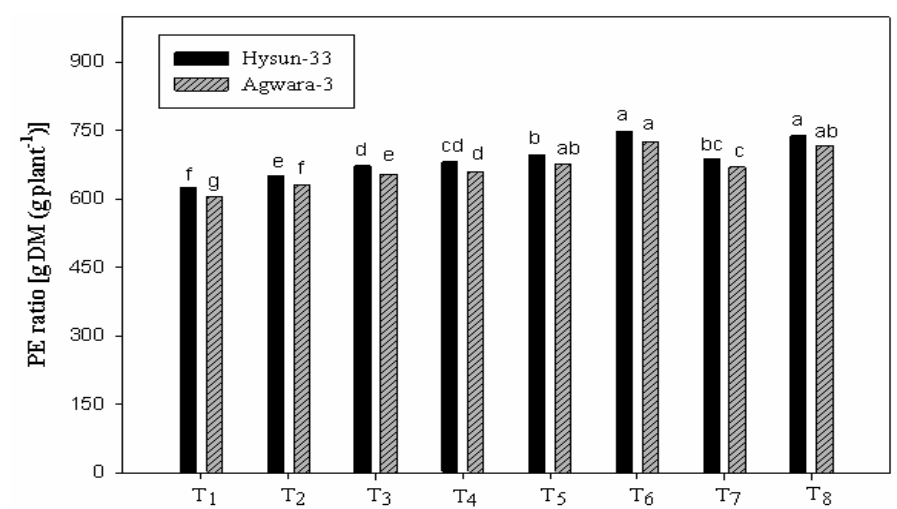

Figure 4: Effect of different $P$ combinations on $P E$ ratio $[g D M(g$ plant $\left.\left.^{-1}\right)\right]$ of sunflower grown under $P$ deficient environment.

\section{Conclusions and Recommendations}

It is clearly showed that different phosphorus combinations significantly influenced sunflower cultivars efficiency for $\mathrm{P}$ uptake. Among the tested sunflower cultivars, Hysun-33 showed superiority over Agwara-4. However, among all the treatments, the application of $\mathrm{NK}+\mathrm{RP}$ at $7 \mathrm{~g}$ pot $^{-1}+$ Wheat straw at $28 \mathrm{~g} \mathrm{pot}^{-1}\left(\mathrm{~T}_{6}\right)$ produced highest values of $\mathrm{P}$ accumulation or concentration, $\mathrm{P}$ uptake efficiency and $\mathrm{PE}$ ratio in cultivar Hysun-33. It is recommended that to obtain optimum growth and yield application of $\mathrm{NK}+\mathrm{RP}$ at $7 \mathrm{~g} \mathrm{pot}^{-1}+$ Wheat straw at $28 \mathrm{~g}$ pot $^{-1}$ was used with Hysun-33 under $\mathrm{P}$ deficit environment.

\section{Novelty Statement}

The study is novel as it investigates that organic amendments improve phosphorus utilization efficiency by sunflower from sparingly soluble $\mathrm{P}$ source under $\mathrm{P}$ deficient environment.

\section{Author's Contribution}

Hafiz Hammad: Carried out the study.

Mukkram Ali Tahir: Designed and supervised the study.

Noor-us-Sabah: Co-supervised the research.

Ghulam Sarwar: Assisted technically.

Muhammad Aftab: Drafting of study.

Muhammad Zeeshan Manzoor and Aneela Riaz:

statistical analysis of data.
Abid Niaz and Muhammad Arif: Proof reading.

\section{Conflict of interest}

The authors have declared no conflict of interest.

\section{References}

Abbadi, J. and J. Gerendás. 2011. Effects of phosphorus supply on growth, yield, and yield components of safflower and sunflower. J. Plant Nutr., 34: 1769-1787. https://doi.org/10.1080/ 01904167.2011 .600405

Abbadi, J. and J. Gerendás. 2012. Phosphorus use efficiency of safflower (Carthamus tinctorius L.) and sunflower (Helianthus annuus L.) studied in nutrient solution. J. Agric. Sci. Technol., 2: 1260-1280.

Abbadi, J., 2007. Importance of nutrient supply $(\mathrm{N}, \mathrm{P}, \mathrm{K})$ for yield formation and nutrient use efficiency of safflower (Carthamus tinctorius L.) compared to sunflower (Helianthus annuus L.) including an assessment to grow safflower under north German conditions. (Doctoral dissertation, Christian-Albrechts Universität Kiel).

Abbadi, J., 2017. Phosphorus use efficiency of safflower and sunflower grown in different soils. World J. Agric. Res., 5(4): 212-220. https://doi. org/10.12691/wjar-5-4-3

Ahmad, N. and M. Rashid. 2003. Fertilizers and their use in Pakistan. Govt. Pakistan, Planning and Development Division, NFDC, Islamabad, Pakistan.

Ali, J., J. Bakht, M. Shafi, S. Khan and W.A. Shah. 2002. Uptake of nitrogen as affected by various combinations of nitrogen and phosphorus. Asian J. Plant Sci., 1: 367-369. https://doi. org/10.3923/ajps.2002.367.369

Ayub, M., M.A. Nadeem, M.S. Sharar and N. Mahmood. 2002. Response of maize (Zea mays L.) fodder to different levels of nitrogen and phosphorus. Asian J. Plant Sci., 1: 352-354. https://doi.org/10.3923/ajps.2002.352.354

Aziz, T., Rahmatullah, M.A. Maqsood, M.A. Tahir, I. Ahmad and M.A. Cheema. 2006. Phosphorus utilization by six brassica cultivars (Brassica juncea L.) from tri-calcium phosphate, a relative insoluble compound. Pak. J. Bot., 38: 1529-1538.

Borredon, M.E., M. Berger, S. Dauguet, F. Labalette, A. Merrien, Z. Mouloungui and Y. 
Raoul. 2011. Débouchés actuels et futures du tournesol produit en France Critères de qualité. Innov. Agron., 14: 19-38.

Chen, M.L., X.L. Jiang, B.Y. Zoov and Z.Y. Zheri. 1994. Mathematical models and best combination of high yield cultivation technique for rapeseed variety $Z$ henyouyoum. Acta Agric. Zhejiiangenesis, 6: 22-26.

Diepenbrock, W. and G. Pasda. 1995. Sunflower (Helianthus annus L.). In: Advances in Plant Breeding 17, eds. W. Diepenbrock, and H.C. Becker, Berlin: Blackwell WissenschaftsVerlag. pp. 91-148.

Economic Survey of Pakistan. 2018-2019. Agricultural statistics of Pakistan. Ministry of Food, Agriculture and Livestock. Government of Pakistan, Islamabad.

FAO, 2014. FAOSTAT. Food and Agriculture Organization of the United Nations, Rome, Italy. http://www.fao.org/faostat/en/

Gahoonia, T.S., F. Asmar, H. Giese, G.G. Nielsen and N.E. Nielsen. 2000. Root released organic acids and phosphorus uptake of two barley cultivars in laboratory and field experiments. Eur. J. Agron., 12: 281-289. https://doi. org/10.1016/S1161-0301(00)00052-6

Gerloff, G.C. and W.H. Gabelman. 1983. Genetic basis of inorganic plant nutrition. In: Encyclopedia of plant physiology, ed., A Läuchli, and R. L. Bieleski, New York, NY: Springer Verlag. Pp. 453-480.

Hussain, N., A.Z. Khan, H. Akbar and S. Akhtar. 2006. Growth factors and yield of maize as influenced by phosphorus and potash fertilization. Sarhad J. Agric., 22(4): 579-583.

Kaffka, S.R., T.E. Kearny, P.D. Knowles and M.D. Miller.2001. Safflower production in California. http://agric.ucdavis.edu/crop/oilseed/saff"oil. htm.

Memon, K.S., 2005. Soil and fertilizer phosphorus. In: Bashir, A. and R. Bantel (eds.), Soil Sci., National Book Foundation, Islamabad, Pakistan. pp. 291-316.

Mohanty, S., N.K. Paikaray and Z. Rajan. 2006. Availability and uptake of phosphorus from organic manures in groundnut (Arachis hypogea L.) sequence using radio tracer technique. Geoderma, 133: 225-230. https://doi. org/10.1016/j.geoderma.2005.07.009

Moll, R.H., E.J. Kamprath and W.A. Jackson. 1982. Analysis and interpretation of factors which contribute to efficiency of nitrogen utilization. Agron. J., 74: 562-564. https://doi. org/10.2134/agronj1982.00021962007400030 $037 \mathrm{x}$

Prolea, 2012. De la production à la consommation. Statistiques des Oléagineux et Protéagineux. Prolea Documentation, Paris, pp. 48.

Soomro, F., N.A. Talpur, M.K. Soothar, S.B. Jamro, A.A. Panhwar, N.A. Memon, J.K. Soothar, U. Ali and M.H. Soomro. 2018. Identification of phosphorus use efficiency of different sunflower genotypes at Tandojam-Pakistan. Pure Appl. Biol., 7(3): 1026-1037. https://doi. org/10.19045/bspab.2018.700122

Steel, R.G.D., J.H. Torrie and D.A. Dichey. 1997. Principles and procedures of statistics: A biometrical approach, $3^{\text {rd }}$ Ed. McGraw Hill Book Co., New York, USA.

Wojnowska, T., H. Panak and S. Seikiewiez. 1995. Reaction of winter oilseed rape to increasing levels of nitrogen fertilizer application under condition of Ketizyn Chernozem. Rosling Oleiste, 16: 173-180. 